\section{Science in the Universities}

The report "Science in the Universities" sub. mitted by the Association of Scientific Workers to the University Grants Committee, March 1944, which has now been published, covers very little ground that has not already been dealt with by the reports from the Parliamentary and Scientific Committee, the Association of University Teachers, or the Nuffield College statements. It is limited to consideration of the physical and biological sciences and the applied sciences immediately related to them such as are normally taught in universities, with some attention to the social sciences; within these limits, it is one of the best guides that has appeared to the ways in which the rapid expansion of scientific knowledge and its application are affecting the universities, and to the measures required to deal with the immediate problems. Among the recommendations may be mentioned those stressing practical work in the vacations as part of the training of all scientific workers, not merely those training for industry; the emphasis on the education and training of laboratory technicians, and also on the technique of teaching.

The report supports the proposal for a universities academic council to co-ordinate the development of research, and also advocates research committees in each university to watch over the development of research, and administer the Government grant for research. Stress is also laid on the extension of maintenance grants, especially in post-graduate work, and the improvement of salaries and conditions of service. The report visualizes a doubling of the 1939 undergraduate population within four years after the War. The capital eost of the accommodation required, including a possible trebling of science departments, is estimated at not less than $£ 30$ millions over ten to twenty years, with an increase in annual expenditure to $£ 15$ millions within five years and to $£ 20$ millions after ten years. Doubling the Government grant in the first full academic post-war year, with an increase to $£ 9$ millions in the fifth year, is recommended.

\section{Standard Frequency Broadcasts}

Some slight modifications have recently been made in the radio transmissions of standard frequencies broadcast by the U.S. National Bureau of Standards from station $W W V$. A new radio frequency at $2.5 \mathrm{Mc}$./sec. now operates from 23.00 until 13.00 U.T. ; and the time signals have been modified by the omission of the pulse on the 59th second of every minute. The service now comprises standard radio frequencies of $2 \cdot 5,5,10$ and $15 \mathrm{Mc}$./sec., at least three of which are available at any time; standard audio frequencies of 440 and 4,000 c./sec. broadcast on these carriers; and interruptions of these broadcasts which constitute accurate time signals synchronized with the basic time service of the U.S. Naval Observatory. The time signals, which are available throughout the 24 hours, consist of pulses of 0.005 sec. duration at intervals of 1 sec. on all the carrier frequencies, and of 1 -min. interruptions of the modulating frequencies every $5 \mathrm{~min}$. The seconds pulses are heard as faint ticks which provide useful standards of short time intervals for physical measurements as well as serving their main function as accurate time signals. On the 59th second of every minute the pulse is omitted.

The 1-min. interval in the audio-frequency transmission is used to give the station announcement, either in Morse or (at the hour and half-hour) orally, and it also permits use of the radio frequencies uncomplicated by the presence of the low frequencies. The accuracy of all the frequencies, radio and audio, as transmitted, is higher than 1 part in $10^{7}$. The intervals given by the seconds pulses are correct to $10^{-5}$ sec. The 1-min., 4-min. and 5-min. intervals marked by the interruption and resumption of the modulating frequencies are accurate to 1 part in $10^{7}$. The Astronomer Royal's aniual report remarks of these broadcasts: "A remarkable degree of agreement has been noted in comparisons of both frequency and time; as a time signal, this form of transmission appears to be capable of a very high standard of precision and to be well adapted for accurate comparisons".

\section{International Trade}

A BROADSHEET, "Facts about International Trade" (No. 219), issued by PEP (Political and Economic Planning), describes developments since the P E P report on international trade was published in 1937 , and is intended to form the starting point for a later examination of some of the main problems of postwar international trade. The main conclusions emerging from the report itself and the present broadsheet are, first, that exports are essentially a means of obtaining necessary or desirable imports : neither Britain, the United States nor any other country should export primarily to create home employment; export and import policy should be deliberately related to a nation's balance of payments and to its long-term foreign lending and borrowing. Secondly, trade restrictions and bilateralism were a symptom more than a cause of the decline in world trade afier 1929; post-war policy should aim at a continuing expansion of effective world demand, making full use of the world's man-power and resources. Multilateral trade, while creating the necessary conditions for obtaining the greatest possible advantages from international trade, also heightens the economic interdependence of nations. A restoration of multilateral trade requires : (a) an efficient international monetary exchange clearing system in which all nations have complete confidence; $(b)$ the maintenance of full employment within national economies; (c) the maximum attainable measure of political security. These three requirements are essential to a universal 'economy of peace'. Failing the establishment of a universal multilateral system of trade, the 'low-tariff club' represents a means by which nations most dependent on international trade can secure the benefits of multilateralism on a limited scale. 'Lend-lease' is essentially a war-time method of international exchange and is unlikely to continue after the immediate post-war period of securities ; but world prosperity, like peace, is indivisible. Finally, Great Britain's major problem in foreign trade after the War is to increase her visible exports very considerably, to repair the inroads of war here and in overseas investment income, and to maintain the volume of imports vital to her standard of living.

\section{Soviet Academy of Sciences in Western Siberia}

Ir is announced in the Soviet War News that a new branch of the Soviet Academy of Sciences has been opened in western Sileria to direct scientific activities in the territory stretching from the Ural Mountains to the banks of the Yenisei, and from the Arctic coast to China and Central Asia. It is believed that 